\begin{tabular}{|c|c|}
\hline 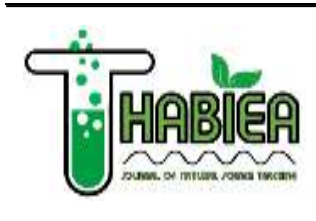 & $\begin{array}{l}\text { Thabiea : Journal of Natural Science Teaching } \\
\text { Program Studi Tadris Ilmu Pengetahuan Alam } \\
\text { Institut Agama Islam Negeri Kudus } \\
\text { http://journal.stainkudus.ac.id/index.php/Thabiea } \\
\text { p-issn: } 25808474\end{array}$ \\
\hline
\end{tabular}

\title{
PCK Model Shulman Berdasarkan Pengalaman Mengajar Guru Fisika
}

\author{
Diah Mulhayatiah ${ }^{\mathrm{a}, 1^{*}}$, Neng Ayu Esti Ramdiani ${ }^{\mathrm{a}, 2}$, Winda Setya ${ }^{\mathrm{a}, 3}$, Herni Yuniarti Suhendi ${ }^{\mathrm{a}, 4}$, Dedi \\ Kuntadi ${ }^{\mathrm{a}, 5}$ \\ aProgram Studi Pendidikan Fisika, UIN Sunan Gunung Djati, Jl. AH. Nasution No. 105, Bandung 40614, \\ ${ }^{1}$ diahmulhayatiah@uinsgd.ac.id; ${ }^{2}$ ayu.estyramadhani@gmail.com; ${ }^{3}$ winda.setya @uinsgd.ac.id; ${ }^{4}$ herni.suhendi@ uinsgd.ac.id; \\ 5dedikuntadi@uinsgd.ac.id \\ *diahmulhayatiah@uinsgd.ac.id
}

\begin{tabular}{ll}
\hline Kata kunci: & ABSTRAK \\
\hline Pengetahuan konten & Tujuan dari penelitian ini adalah untuk menentukan kompetensi PCK \\
Mengajar pengalaman & dengan model Shulman guru fisika berdasarkan pengalaman mengajar. \\
Subject matter & Metode penelitian yang digunakan adalah deskriptif kualitatif dengan \\
Kompetensi guru & analisis wacana. Subyek penelitian adalah dua guru fisika di sekolah \\
& menengah. Hasil penelitian menunjukkan bahwa guru fisika yang \\
& memiliki pengalaman mengajar lebih lama lebih fleksibel, terfokus pada \\
& kedalaman materi dan lebih bervariasi dalam menggunakan model \\
& pembelajaran, sedangkan guru dengan pengalaman mengajar yang buruk \\
& fokus pada kedalaman materi. Berdasarkan hasil ini dapat diketahui \\
& karakteristik mengajar guru berdasarkan pengalaman mengajar. Studi ini \\
& berguna sebagai rekomendasi bagi para pemangku kepentingan untuk \\
menentukan sejauh mana integrasi kompetensi pedagogis dan konten dari & masing-masing guru.
\end{tabular}

\begin{tabular}{ll}
\hline Key word: & ABSTRACT \\
\hline Content knowledge & Shulman's PCK based on Teaching Experience of Physics Teachers. \\
Experience teaching & The purpose of this study was to determine the PCK competencies with \\
Subject matter & Shulman models of physics teacher based on teaching experience. The \\
Teacher competencies & research method used is descriptive qualitative with discourse analysis. \\
& The research subjects were two physics teachers in secondary schools. The \\
& results showed that physics teachers who had longer teaching experience \\
& were more flexible, focused on the depth of material and more varied in \\
& using the learning model, whereas teachers with poor teaching experience \\
focus on the depth of the material. Based on these results it can be known \\
the teaching characteristics of teachers based on teaching experience. This \\
study is useful as a recommendation for stakeholders to determine the \\
extent of integration of pedagogical and content competencies of each \\
teacher.
\end{tabular}

Copyright (C) 2018 Institut Agama Islam Negeri Kudus. All Right Reserved

\section{Pendahuluan}

Pendidikan dapat dipengaruhi oleh beberapa faktor seperti kurikulum, infrastruktur, kemampuan siswa, sumber belajar dan sebagainya. Guru adalah salah satu sumber belajar bagi siswa. Guru adalah sosok dalam pelaksanaan pendidikan karena guru adalah sosok yang dibutuhkan dalam memacu keberhasilan siswa dalam belajar. Hal ini sejalan dengan apa yang dinyatakan oleh
Koehler bahwa seorang guru harus memiliki motif dan tujuan, menganalisis persepsi pribadi dari persiapan mengajar dan mengeksplorasi hambatan untuk pengajaran yang sukses (Koehler, Feldhaus, Fernandez, \& Hundley, 2013).

Keterampilan seorang guru dalam mengajar merupakan faktor penting dalam menentukan kualitas pembelajaran yang dapat mempengaruhi peningkatan pembelajaran dan 
pengembangan motivasi belajar siswa (Baumert et al., 2010). Seorang guru dituntut untuk memiliki empat jenis kompetensi, yaitu kompetensi pribadi, kompetensi pedagogis, kompetensi profesional, dan kompetensi sosial (Hendri, 2010).

Guru yang ingin mengajar sains secara efektif harus lebih dari sekedar mengetahui tentang konten (konten) yang akan diajarkan dan beberapa cara mengajar. Guru juga harus memahami dan dapat mengintegrasikan pengetahuan konten ke dalam pengetahuan tentang kurikulum pembelajaran, pengajaran dan siswa. Shulman menjelaskan bahwa pengetahuan ini pada akhirnya dapat menyebabkan guru untuk mengumpulkan situasi belajar dalam kebutuhan individu dan kelompok siswa, pengetahuan ini adalah PCK (Cochran, DeRuiter, \& King, 1993). PCK adalah konstruksi akademik yang menggambarkan ide yang menggambarkan minat dalam mempelajari sesuatu. PCK adalah pengetahuan yang dikembangkan oleh guru dari waktu ke waktu dan melalui pengalaman tentang cara mengajarkan konten tertentu dengan cara tertentu untuk meningkatkan pengalaman peserta didik (Loughran, Mulhall, \& Berry, 2008).

PCK adalah pengetahuan yang dikembangkan oleh guru dari waktu ke waktu dan melalui pengalaman tentang bagaimana mengajarkan konten tertentu dengan cara tertentu untuk meningkatkan pengalaman siswa PCK dari seorang guru bisa sama dengan guru lain, tetapi juga bisa berbeda . Hal ini dipengaruhi oleh konteks pengajaran, penguasaan konten dan pengalaman guru.

Seorang guru membutuhkan pemahaman konsep yang kaya tentang materi pelajaran yang mereka ajarkan. Pemahaman konseptual yang kaya dikombinasikan dengan keahlian dalam menggunakan prosedur pengajaran, strategi dan pendekatan, untuk digunakan di ruang kelas, menciptakan campuran pengetahuan konten dan pengetahuan pedagogis yang dinyatakan sebagai PCK (Shulman, 1999)
Pengalaman mengajar guru juga merupakan salah satu hal yang mempengaruhi peningkatan PCK guru. Penelitian ini pertama kali dilakukan oleh Shulman, yang merupakan perbandingan antara ahli dan pemula tetapi berdasarkan Model Pedagogical Reasoning (Gudmundsdottir \& Shulman, 1987). Idealnya semakin lama guru mengajar dan berinteraksi dengan siswa maka semakin baik kompetensi PCK. Penelitian ini berfokus pada rincian PCK guru berdasarkan pengalaman mengajar guru di sekolah. Selain itu, Gudmundsdottir dan Shulman juga menyatakan bahwa dalam persiapan dan pengajaran, guru memanfaatkan sumber pengetahuan yang diidentifikasi: pengetahuan konten, pengetahuan konten pedagogis, pengetahuan kurikuler, pengetahuan pedagogis umum, pengetahuan tentang tujuan dan tujuan, pengetahuan peserta didik, dan pengetahuan konteks pendidikan, pengaturan dan tata kelola.

Lingkungan belajar di abad 21 yang baru ini membutuhkan tuntutan sehingga perlu untuk mengkonseptualisasikan pengajaran fisika dan mata pelajaran lain dan akibatnya, kebiasaan yang harus dikembangkan oleh fisika atau guru lain (Etkina, Gregorcic, \& Vokos, 2017). Kualitas dan pemahaman, keterampilan dan kemampuan, dan apa sifat dan kepekaan membuat seseorang seorang guru yang kompeten terus bergema di ruang konferensi pendidik selama beberapa generasi (Shulman, 1986).

Abell menjelaskan bahwa guru tidak memiliki pengetahuan mata pelajaran dalam sains, dan tidak tahu banyak tentang bagaimana anak-anak berpikir secara ilmiah atau apa yang diajarkan ide sains (strategi, representasi, demonstrasi) dapat digunakan untuk membantu siswa mempelajari berbagai konsep sains (Abell, 2008).

Shulman juga menggambar bahwa pengetahuan konten pedagogis dibangun di atas bentuk pengetahuan profesional lainnya, dan ada elemen konstitutif penting dalam basis pengetahuan mengajar (Park, Jang, Chen, \& Jung, 2011). Fernandez menjelaskan PCK 
adalah konstruksi yang telah banyak digunakan dalam literatur tentang pengetahuan guru dengan pengetahuan profesional tertentu dan telah terbukti menjadi model yang bermanfaat untuk penyelidikan yang bertujuan untuk mendokumentasikan pengetahuan yang membuat seorang guru yang baik (Fernandez, 2014).

Mengajarkan orientasi melibatkan mengadopsi beberapa metode pengajaran dan menolak yang lain. Ini berarti bahwa guru akan mengembangkan repertoar metode pengajaran yang mereka yakini selaras dengan ide-ide yang mereka yakini penting bagi siswa untuk belajar (Gudmundsdottir, 1987).

\section{Metode Penelitian}

Metode penelitian yang digunakan adalah analisis wacana. Analisis wacana digunakan karena masalah yang diangkat adalah studi tentang analisis profil wacana pedagogis guru dengan menuntut data lapangan aktual dan kontekstual. Data utama yang diperoleh dalam penelitian ini berupa rekaman audio visual proses belajar mengajar guru fisika di kelas yang kemudian diubah menjadi teks atau transkripsi. Penelitian yang dilaporkan di sini menawarkan cara PCK mengungkap, mengartikulasikan, dan mendokumentasikan guru sains yang, kami percaya, menciptakan peluang asli untuk berbagi pengetahuan ini dalam komunitas profesional dengan cara yang berarti, berguna, dan berharga bagi guru, guru pendidik, dan sains. peneliti pendidikan (Loughran, Mulhall, \& Berry, 2004).

Data penelitian diperoleh dengan melakukan analisis wacana dari proses pembelajaran dua guru fisika sekolah menengah yang berbeda dalam panjangnya pengajaran. Guru A mengajar lebih dari 23 tahun dan Guru B mengajar kurang dari 5 tahun. Data juga diperoleh dari lembar observasi yang berisi tujuh komponen PCK model Shulman dan wawancara. Ini karena PCK menganalisis bagian pertama dari membangun kerangka teoretis apa pun untuk mengidentifikasi apa yang penting untuk membangun fenomena yang menarik (Graham, 2011). Ketujuh komponen yang dirumuskan oleh Shulman adalah (1) pengetahuan materi pelajaran; (2) pengetahuan pedagogis umum; (3) pengetahuan tentang konten pedagogi; (4) pengetahuan kurikulum; (5) pengetahuan siswa dan karakteristik mereka; (6) pengetahuan tentang strategi pengajaran; (7) pengetahuan tentang konteks pembelajaran (Shulman, 1999) Seorang guru yang baik harus dapat menguasai konten dan menguasai ilmu pengajaran untuk menciptakan pembelajaran yang berarti bagi siswa dan dapat mengemas materi tertentu sehingga mudah diterima oleh siswa.

\section{Hasil dan pembahasan}

Proses pembelajaran secara garis besar diuraikan sebagai berikut: guru membagi siswa menjadi beberapa kelompok dan kemudian membahas dua karakteristik karakteristik gelombang yaitu refleksi dan refraksi. Dalam sifat mencerminkan guru menunjukkan penerapan refleksi yang melibatkan siswa. Guru melakukan percobaan pada properti refraksi untuk menunjukkan sifat bias, setelah itu siswa mempresentasikan hasil percobaan. Pada akhir pembelajaran, guru memberikan pekerjaan rumah dalam bentuk mencari informasi tentang persamaan pergeseran besar

Data penelitian berupa transkrip rekaman video kegiatan pembelajaran dan transkrip wawancara guru yang menjadi responden. Transkip video dan proses pengahalusan untuk menjadi teks dasar.

Pada pertemuan pertama diketahui bahwa sebanyak 33 indikator kedua pengamat sepakat memilih ya, 2 indikator kedua pengamat sepkat memilih tidak ya dan 7 indikator kedua pengamat meilih tidak, sedangkan pada pertemuan kedua 32 indikator kedua pengamat sepakat memilih ya dan 10 indikator kedua pengamat sepakat memilih tidak. Sehingga dapat dicari koefesien kontingensinya dengan persamaan sebagai berikut:

$$
K K=\frac{2 S}{N_{1}+N_{2}}
$$




$$
\begin{gathered}
S=33+7=40 \\
N_{1}=42 \\
N_{2}=42 \\
K K=\frac{2.40}{42+42}=\frac{80}{82}=0,98
\end{gathered}
$$

Menurut Chiappetta (1991) hasil tersebut menunjukkan sangat baik karena diatas 0,75 dan hasil 0,98 menunjukan bahwa kedua pengamat sepakat dengan setiap indikator yang dibuat terhadap kemunculannya PCK model Shulman pada guru A (Chiappetta, Fillman, \& Sethna, 1991).

Pertemuan Kedua

$$
\begin{aligned}
& K K=\frac{2 S}{N_{1}+N_{2}} \\
& S=32+10=42 \\
& N_{1}=42 \\
& N_{2}=42 \\
& K K=\frac{2.42}{42+42}=\frac{82}{82}=1
\end{aligned}
$$

Menurut Chiappetta (1991) hasil tersebut menunjukkan sangat baik karena diatas 0,75 dan hasil 1 menunjukan bahwa kedua pengamat sepakat dengan setiap indikator yang dibuat terhadap kemunculannya PCK model Shulman pada guru A.

Pada pertemuan pertama diketahui bahwa sebanyak 31 indikator kedua pengamat sepakat memilih ya, 2 indikator kedua pengamat sepakat memilih ya tidak, 2 indikator pengamat sepakat memilih tidak ya, dan 7 inddikator kedua pengamat meilih tidak, sedangkan pada pertemuan kedua 32 indikator kedua pengamat sepakat memilih ya dan 10 indikator kedua pengamat sepakat memilih tidak. Sehingga dapat dicari koefesien kontingensinya dengan persamaan sebagai berikut:

Pertemuan pertama

$$
\begin{aligned}
& K K=\frac{2 S}{N_{1}+N_{2}} \\
& S=31+7=39 \\
& N_{1}=42 \\
& N_{2}=42 \\
& K K=\frac{2.39}{42+42}=\frac{78}{82}=0,97
\end{aligned}
$$

Menurut Chiappetta (1991) hasil tersebut menunjukkan sangat baik karena diatas 0,75 dan hasil 0,97 menunjukan bahwa kedua pengamat sepakat dengan setiap indikator yang dibuat terhadap kemunculannya PCK model Shulman pada guru FL.

Pertemuan pertama

$$
\begin{aligned}
& K K=\frac{2 S}{N_{1}+N_{2}} \\
& S=32+10=42 \\
& N_{1}=42 \\
& N_{2}=42 \\
& K K=\frac{2.42}{42+42}=\frac{82}{82}=1 \\
& \text { Menurut Chiappetta (1991) hasil }
\end{aligned}
$$
tersebut menunjukkan sangat baik karena diatas 0,75 dan hasil 1 menunjukan bahwa kedua pengamat sepakat dengan setiap indikator yang dibuat terhadap kemunculannya PCK model Shulman pada guru B.

Berdasarkan pengamatan selama pengumpulan data dan dari pencatatan proses pembelajaran yang telah dilakukan oleh Guru A dan Guru B, terlihat bahwa kedua guru memiliki banyak perbedaan dalam pembelajaran di kelas. Data penelitian berupa transkrip rekaman video kegiatan pembelajaran dan transkrip wawancara guru yang menjadi responden. Salah satu transkrip kegiatan pembelajaran di PCK dengan menganalisis materi pelajaran untuk menentukan tingkat kesulitan. Sebuah transkrip guru A memiliki lebih dari 20 tahun pengalaman mengajar Pelajaran pertama

Guru: Apa pendapat Anda tentang orang lain? Sebutkan properti gelombang?

Siswa: Refleksi, refraksi, meregangkan, penambahan dan polarisasi

Pelajaran kedua

Guru: cobalah siapa yang bisa menulis aplikasi gelombang dalam kehidupan sehari-hari

Siswa: salah satu siswa maju

Transkrip guru B yang memiliki pengalaman mengajar kurang dari 5 tahun adalah 
Pelajaran pertama

Guru: Hari ini kita akan belajar tentang sifat gelombang mekanik, salah satunya adalah?

Siswa: refleksi

Pelajaran kedua

Guru: Hari ini kita akan belajar refraksi, difraksi dan gangguan, kita akan bermain sedikit hari ini, aturan pertama adalah kelas dibagi menjadi beberapa kelompok, Anda ingin Anda menghitung dari 1-6?

Siswa: bisakah Anda mengepak (serempak)

Transkripsi di atas menunjukkan bahwa guru kompetensi A lebih bisa untuk mengeksplorasi aktivitas siswa dengan memberikan banyak pertanyaan aktif untuk dijawab oleh siswa, sementara guru B hanya menekankan pertanyaan pasif. Hasil observasi diperoleh data sebagai berikut:

Tabel 1. PCK Competencies

\begin{tabular}{lcccc}
\hline \hline $\begin{array}{l}\text { Aspects of } \\
\text { PCK } \\
\text { Competency }\end{array}$ & $\begin{array}{c}\text { Lesson 1 } \\
\text { r A }\end{array}$ & $\begin{array}{c}\text { Teache } \\
\text { r B }\end{array}$ & $\begin{array}{c}\text { Teache } \\
\text { r A }\end{array}$ & $\begin{array}{c}\text { Teache } \\
\text { r B }\end{array}$ \\
\hline $\begin{array}{l}\text { Subject } \\
\text { Material }\end{array}$ & $100 \%$ & $100 \%$ & $100 \%$ & $100 \%$ \\
$\begin{array}{l}\text { Knowledge } \\
\text { General }\end{array}$ & $100 \%$ & $100 \%$ & $100 \%$ & $100 \%$ \\
$\begin{array}{l}\text { Pedagogy } \\
\text { Knowledge } \\
\text { Pedagogical } \\
\text { Content }\end{array}$ & $66 \%$ & $66 \%$ & $60 \%$ & $60 \%$ \\
$\begin{array}{l}\text { Knowledge } \\
\text { Curriculum }\end{array}$ & $75 \%$ & $50 \%$ & $75 \%$ & $50 \%$ \\
$\begin{array}{l}\text { Knowledge } \\
\text { Learner } \\
\text { knowledge } \\
\text { and } \\
\text { characteristi }\end{array}$ & $80 \%$ & $80 \%$ & $80 \%$ & $80 \%$ \\
cs & & & & \\
$\begin{array}{l}\text { Teaching } \\
\text { Strategy }\end{array}$ & $83 \%$ & $100 \%$ & $100 \%$ & $100 \%$ \\
$\begin{array}{l}\text { Knowledge } \\
\text { Knowledge } \\
\text { of Learning } \\
\text { Context }\end{array}$ & $100 \%$ & $75 \%$ & $100 \%$ & $100 \%$ \\
\hline \hline
\end{tabular}

Tabel 1 menjelaskan secara rinci persentase aspek PCK guru berdasarkan transkrip pembelajaran. Kriteria pertama mengenai pengetahuan mata pelajaran terdiri dari enam indikator, setelah dianalisis dalam pertemuan pertama dan pertemuan baik guru A dan guru B memenuhi enam indikator. Sehingga setelah perhitungan persentase untuk kriteria pertama adalah $100 \%$.

Kriteria kedua adalah pengetahuan pedagogi umum yang terdiri dari empat indikator, setelah dianalisis dalam pertemuan pertama dan pertemuan baik guru A dan guru B memenuhi empat indikator. Sehingga setelah perhitungan persentase untuk kriteria kedua adalah $100 \%$.

Kriteria ketiga adalah tentang pengetahuan konten pedagogis yang terdiri dari lima belas indikator, setelah dianalisis dalam pertemuan pertama guru A dan guru B memenuhi sepuluh indikator sehingga setelah perhitungan persentase untuk kriteria ketiga adalah $66 \%$, sementara pertemuan kedua guru A dan guru B memenuhi sembilan indikator sehingga setelah persentase dihitung untuk kriteria ketiga adalah 60\%. Perbedaan antara pertemuan pertama dan pertemuan antara dua guru adalah karena pada pertemuan pertama $\mathrm{A}$ dan guru B memenuhi indikator berlatih dan berinteraksi dengan siswa sementara dalam pertemuan tersebut baik guru $\mathrm{N}$ dan guru $\mathrm{B}$ tidak memenuhi indikator.

Kriteria keempat tentang pengetahuan kurikulum terdiri dari empat indikator, setelah dianalisis dalam pertemuan pertama dan kedua guru A memenuhi tiga indikator sehingga setelah kriteria keempat dihitung persentasenya adalah $75 \%$ sedangkan guru kedua dalam pertemuan pertama dan yang kedua bertemu memenuhi dua indikator sehingga setelah kriteria keempat dihitung persentasenya adalah $50 \%$. Perbedaan ini disebabkan oleh guru A memenuhi indikator yang memiliki materi pembelajaran yang relevan sementara guru B tidak memenuhi indikator.

Kriteria kelima tentang pengetahuan pembelajar dan karakteristiknya terdiri dari lima indikator. Pada pertemuan pertama dan pertemuan baik guru A dan guru B bertemu empat indikator. Hasil perhitungan persentase untuk kriteria kelima adalah $80 \%$.

Kriteria keenam mengenai manajemen strategi pengajaran terdiri dari enam indikator 
setelah dianalisis oleh pertemuan pertama dan kedua untuk guru. A memenuhi lima indikator dengan persentase untuk kriteria keenam adalah 83\%. Guru B pada pertemuan pertama dan pertemuan kedua memenuhi enam indikator sehingga setelah persentase dihitung untuk kriteria keenam adalah $100 \%$

Kriteria ketujuh pada pengetahuan konteks pembelajaran terdiri dari empat indikator setelah dianalisis pertemuan pertama guru A memenuhi empat indikator sehingga setelah perhitungan persentase untuk kriteria ketujuh adalah 100\% sedangkan guru B memenuhi 3 indikator sehingga setelah persentasenya adalah dihitung untuk kriteria ketujuh adalah $75 \%$. Hal ini karena pada pertemuan pertama guru memenuhi indikator untuk membina kerjasama yang baik antara siswa ketika belajar di kelas sementara guru B tidak memenuhi. Pada pertemuan kedua guru $\mathrm{A}$ dan guru B bertemu empat indikator sehingga setelah persentase dihitung untuk kriteria ketujuh adalah $100 \%$.

Deskripsi interaksi guru dan siswa dianalisis per aspek PCK untuk menggambarkan sejauh mana kompetensi guru PCK dapat diilustrasikan, hal ini sebagaimana dinyatakan oleh Goodhew memainkan peran pengetahuan konten dalam memilih pemikiran siswa mereka, dalam mengorganisir dan menyuarakan ide-ide siswa di istilah disiplin, dan meminta siswa untuk memikirkan energi dengan cara disiplin (Goodhew \& Robertson, 2017)

Hasil pengamatan pada semua aspek PCK menjelaskan bahwa guru yang memiliki pengalaman mengajar lebih lama memiliki kompetensi PCK yang lebih baik daripada guru yang kurang pengalaman mengajar. Hal ini sesuai dengan pernyataan kedua dari hasil penelitian Gudmundsdottir ada perbedaan dalam peluang mereka harus mendefinisikan ulang pengetahuan konten mereka untuk membangun pengetahuan konten pedagogis (Gudmundsdottir, 1990)

Namun, ini juga dapat disebabkan oleh hal-hal lain, yaitu terbatasnya jumlah sampel kecil yang belum mampu mewakili kompetensi guru PCK yang ahli dan pemula, kata Hodgen dengan berfokus pada cara PCK aktif di ruang kelas dan hubungannya dengan praktik kelas (Depaepe, Verschaffel, \& Kelchtermans, 2013)

Kompetensi PCK untuk guru dapat meningkat dengan baik jika didukung oleh berbagai aspek pembelajaran termasuk guru, siswa, fasilitas, dan persiapan guru dalam melaksanakan pembelajaran, hal ini sejalan dengan Cochran (1993) yang juga mengatakan bahwa guru dicetak dengan baik dari pembelajaran yang melibatkan konten pengetahuan, pengembangan pembelajaran yang inovatif dan substantif dan harus terus dievaluasi oleh berbagai pihak yang terlibat (Cochran et al., 1993)

Robertson mengatakan, pengembangan profesional guru mendukung guru dalam mengenali dan menanggapi tertanam dalam pembicaraan dan tindakan siswa, bersama dengan atau di samping mendukung guru dalam mengembangkan pengetahuan energi mereka sendiri dan pengetahuan konten pedagogik (Robertson et al., 2017).

\section{Simpulan}

Kompetensi PCK guru, salah satunya ditentukan berdasarkan lama atau tidaknya pengajaran, meskipun ini tidak menjamin bahwa guru yang memiliki pengalaman mengajar yang lama akan memiliki PCK yang baik. Guru yang memiliki pengalaman mengajar yang lebih panjang memiliki kompetensi yang baik di hampir semua aspek PCK, sedangkan bagi mereka yang kurang berpengalaman tidak semua aspek PCK dimiliki. Rekomendasi untuk penelitian lebih lanjut adalah untuk menganalisis kompetensi guru fisika dengan melibatkan pengalaman mengajar dengan mengintegrasikan berbagai disiplin ilmu dan juga latar belakang pendidikan guru. 


\section{Ucapan terima kasih}

Ucapan terima kasih kami sampaikan kepada LP2M yang telah memberikan dana untuk kegiatan penelitian ini.

\section{Referensi}

Abell, S. K. (2008). Twenty years later: Does pedagogical content knowledge remain a useful idea? International Journal of Science Education, 30(10), 1405-1416.

Baumert, J., Kunter, M., Blum, W., Brunner, M., Voss, T., Jordan, A., ... Tsai, Y.-M. (2010). Teachers' mathematical knowledge, cognitive activation in the classroom, and student progress. American Educational Research Journal, 47(1), 133-180.

Chiappetta, E. L., Fillman, D. A., \& Sethna, G. H. (1991). A method to quantify major themes of scientific literacy in science textbooks. Journal of Research in Science Teaching, 28(8), 713-725.

Cochran, K. F., DeRuiter, J. A., \& King, R. A. (1993). Pedagogical content knowing: An integrative model for teacher preparation. Journal of Teacher Education, 44(4), 263-272.

Depaepe, F., Verschaffel, L., \& Kelchtermans, G. (2013). Pedagogical content knowledge: A systematic review of the way in which the concept has pervaded mathematics educational research. Teaching and Teacher Education, 34, 1225.

Etkina, E., Gregorcic, B., \& Vokos, S. (2017). Organizing physics teacher professional education around productive habit development: A way to meet reform challenges. Physical Review Physics Education Research, 13(1), 10107.

Fernandez, C. (2014). Knowledge Base For Teaching And Pedagogical Content Knowledge (PCK): Some Useful Models And Implications For Teachers'training. Problems of Education in the 21st Century, 60.

Goodhew, L. M., \& Robertson, A. D. (2017). Exploring the role of content knowledge in responsive teaching. Physical Review Physics Education Research, 13(1), 10106.

Graham, C. R. (2011). Theoretical considerations for understanding technological pedagogical content knowledge (TPACK). Computers \& Education, 57(3), 1953-1960.

Gudmundsdottir, S. (1987). Pedagogical Content Knowledge: Teachers' Ways of Knowing.

Gudmundsdottir, S. (1990). Values in pedagogical content knowledge. Journal of Teacher Education, 41(3), 44-52.

Gudmundsdottir, S., \& Shulman, L. (1987). Pedagogical content knowledge in social studies. Scandinavian Journal of Educationl Research, 31(2), 59-70.

Hendri, E. (2010). Guru berkualitas: profesional dan cerdas emosi. Jurnal Saung Guru, 1(2), 1.

Koehler, A., Feldhaus, C. R., Fernandez, E., \& Hundley, S. P. (2013). Alternative certification programs \& pre-service teacher preparedness. Journal of STEM Education: Innovations \& Research, 14(4).

Loughran, J., Mulhall, P., \& Berry, A. (2004). In search of pedagogical content knowledge in science: Developing ways of articulating and documenting professional practice. Journal of Research in Science Teaching, 41(4), 370-391.

Loughran, J., Mulhall, P., \& Berry, A. (2008). Exploring pedagogical content knowledge in science teacher education. International Journal of Science Education, 30(10), 1301-1320.

Park, S., Jang, J.-Y., Chen, Y.-C., \& Jung, J. (2011). Is pedagogical content knowledge (PCK) necessary for reformed science teaching?: Evidence from an empirical study. Research in Science Education, 41(2), 245-260.

Robertson, A. D., Scherr, R. E., Goodhew, L. M., Daane, A. R., Gray, K. E., \& Aker, L. B. (2017). Identifying content knowledge for teaching energy: Examples from high school physics. Physical Review Physics Education Research, 13(1), 10105.

Shulman, L. S. (1986). Those who understand: Knowledge growth in teaching. Educational Researcher, 15(2), 4-14.

Shulman, L. S. (1999). Knowledge and teaching: Foundations of the new reform. Learners and Pedagogy, 61-77. 